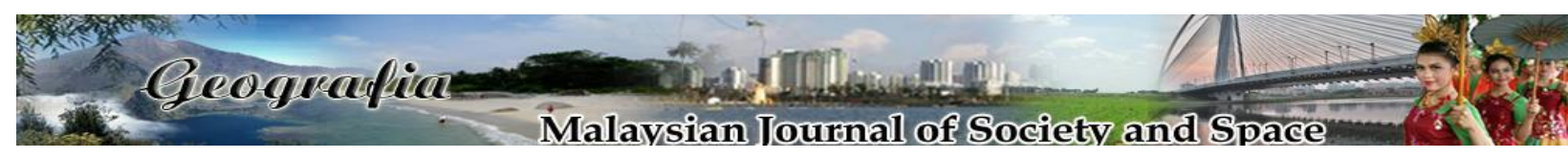

\title{
Solid waste management as a response to urban flood risk in Gujrat city, Pakistan
}

\author{
Sana Ijaz, Muhammad Miandad, Syed Shajee Mehdi, Muhammad Mushahid Anwar, \\ Ghani Rahman \\ Department of Geography, University of Gujrat, Pakistan \\ Correspondence: Muhammad Miandad (email: muhammad.miandad@uog.edu.pk)
}

Received: 07 June 2020; Accepted: 19 November 2020; Published: 27 February 2021

\begin{abstract}
Solid waste generation is directly proportional to the population; it is also increasing with the global population. Pakistan generates 0.283 to $0.612 \mathrm{~kg} /$ capita/day solid waste and per year growth rate is $2.4 \%$. In developing countries the issue of poor solid waste management is prevalent. In Pakistan, 55000 tons solid waste is being generated per day in the urban areas. Only 60\% waste is collected and disposed. The remainder is left uncollected which ultimately causes problems of urban flooding, blockage in sewerage system, and outbreak of numerous diseases. The city generates 210 tons solid waste daily, out of which only 165 tons is being collected and disposed. Similarly, the sewerage system covers $60 \%$ of the residential area with the pipeline ranging from 9 to 51 inches in diameter. There are two drains which carry waste and rain water out of the city. Current research was conducted to find the relation between poor solid waste management (SWM) and problem of Urban Flooding in Gujrat. The data was collected by measuring level of flood water in major chowks of Gujrat for 10 consecutive rainfalls from 09-04-2018 to 23-09-2018. The flood level data was correlated with the other waste dumping sites in Gujrat and the width of drainage system. While other urban flood prone sites were identified by using GIS (interpolation). The results showed that the areas which have a waste dumping facility face more hurdles after rainfall. Approximately 15-20 inches water accumulates in Jail chowk, Jinnah Road, Circular road, Fawara chowk and Ramtlai chowk even after mild rainfalls, and this level increases during heavy rainfalls. Solid waste generation is continuously on a rise. Along with the rise in economic status of general public, their buying capacity is increasing which is putting pressure on the SWM system. Similarly, as Gujrat's population growth is $2.2 \%$ according to the 2017 census, the number of existing sanitary staff is not enough. There is one sanitary cleaner for 900 people, and as the drainage network of Gujrat is poorly constructed, this number in not justifiable.
\end{abstract}

Keywords: Dumping sites, Gujrat, sewerage system, solid waste, urban flood Introduction 
Solid waste is a heterogeneous mass of discarded material from the urban population (Shekdar, 2009). World population is becoming urban rapidly, by 2030 almost $60 \%$ of the world population is expected to live in cities (Bolund \& Hunhammar, 1999). As the urban population is continuously increasing, it is exerting pressure on the urban services (Estoque \& Murayama, 2013). Solid waste management is one of the major public services that the government provides (Tukahirwa, Mol, \& Oosterveer, 2010; SPOANN, 2019). However, in Pakistan waste management is in its worse state. The poor measures to dump and recycle the waste results in blockage of drains and water channels which leads to the risk of urban flooding. These blockages also damage property and produce breeding grounds for toxic materials and diseases (Lamond, Bhattacharya, \& Bloch, 2012).

The population of Pakistan is 200 million of which $37 \%$ people live in urban areas. Almost 55,000 tons per day solid waste is generated in urban areas of Pakistan. But like other developing countries the system of collecting and disposing of this waste is poor (Guerrero, Maas, \& Hogland, 2013), only $60 \%$ of waste is collected while the remaining is openly dumped by the public in the empty plots, drains, and sewers. The location of dumping sites is not properly planned and not enough for continuously increasing population. The landfill sites are also very important in SWM (solid waste management) but here in Pakistan, landfilling is sometimes used during roads construction and that also on a very small scale (Batool \& Ch, 2009).

The waste generated from hospitals, called biomedical waste, is hazardous to public health (Rajor, Xaxa, \& Mehta, 2012). According to WHO, 85\% biomedical waste is almost harmless, $10 \%$ of it can cause infections and $5 \%$ is dangerous but does not necessarily cause infections. Mostly the health care units are in the center of cities, therefore, the flaws in biomedical waste management lead to great potential hazards to public health and environmental sustainability (Radha, Kalaivani, \& Lavanya, 2009).

Solid waste management is one of the major duties of local governments and requires a large part of the budget. Waste management, dumping, and cleaning of streets is often the city's single largest source of employment as it requires large manpower (Bhada, 2007). The waste that is left uncollected and untreated openly triggers local flooding and results in air and water pollution. The percentage of MSW (municipal solid waste) depends upon per-capita income of the residents. In developing and 3rd world countries most of the waste is dumped in open plots, streets etc., which requires more effort and expenses (80 to 90\%) to collect it and then move it to recycling plants (Hoornweg \& Bhada-Tata, 2012).

When heavy rain falls, the water gets mixed with the openly dumped solid waste and eventually, it blocks the drainage lines causing urban floods (Muthuraman \& Ramaswamy, 2019; Raju, Ravindra, Manasi, Smitha, \& Srinivas, 2018). In Pakistan major cities like Karachi, Lahore and Rawalpindi face heavy urban floods in every rainy season. Mostly resulting in the spread of diseases and damaging the properties. The Naala Lai in Rawalpindi is a major source of urban flooding in the area which overflows up to such dangerous levels that the surrounding population is forced to move every year in Monsoon season (Rehman, Chaudhry, \& Nasir, 2015). Similarly, in Karachi, the heavy rainfall in the year 2017 resulted in the sinking of major parts of the city i.e. Paposh Nagar, Khara darr, Layari, Korangi industrial area, and many other improperly planned areas. Most of these areas are poorly maintained and the condition of drains and solid waste management is in its worst state.

The smaller cities are also heavily damaged each year with urban flooding (Gupta \& Nair, 2011) including Gujrat, Gujranwala, Sialkot, and Qasur etc. In the year 2018 Gujrat city again faced heavy rainfall and flooding. The major roads and chowks (roundabouts) of the city were 
blocked making it dangerous to move on them. The busy market areas of the city were sunk in 23 feet of water for many days which definitely was hazardous for public health. It also affected the business activities of the city, as people cannot to move in these days (Khan, Iqbal, \& Yosufzai, 2011)

As Pakistan is still struggling to develop economically, people do not pay much needed attention to environmental stability. Generally people do not bother about the effects they are leaving on their physical environment because of the overall careless behavior. Like numerous other problems, urban flooding should also be eradicated and this is only possible if the general public takes interest in maintaining a smooth solid waste management system. Pakistan generates 0.283 to $0.612 \mathrm{~kg} / \mathrm{capita} /$ day solid waste and per year growth rate is $2.4 \%$ (Mukwana, Samo, Tunio, Jakhrani, \& Luhur, 2014)

\section{Study area}

Situated in the heartland of upper Punjab, Gujrat is present between the river Jhelum and Chenab. The area also known as Chaj doab essentially constitutes parts of Pakistan's version of the Fertile Crescent. The district of Gujrat borders Mirpur district on the north, Jhelum on the north-west, Sialkot and Gujranwala on the south and south-east, and Mandi Baha-Uddin on the west. It covers an area of 3,192 square kilometers making it one of the smallest districts of Punjab by area (Figure $1)$.

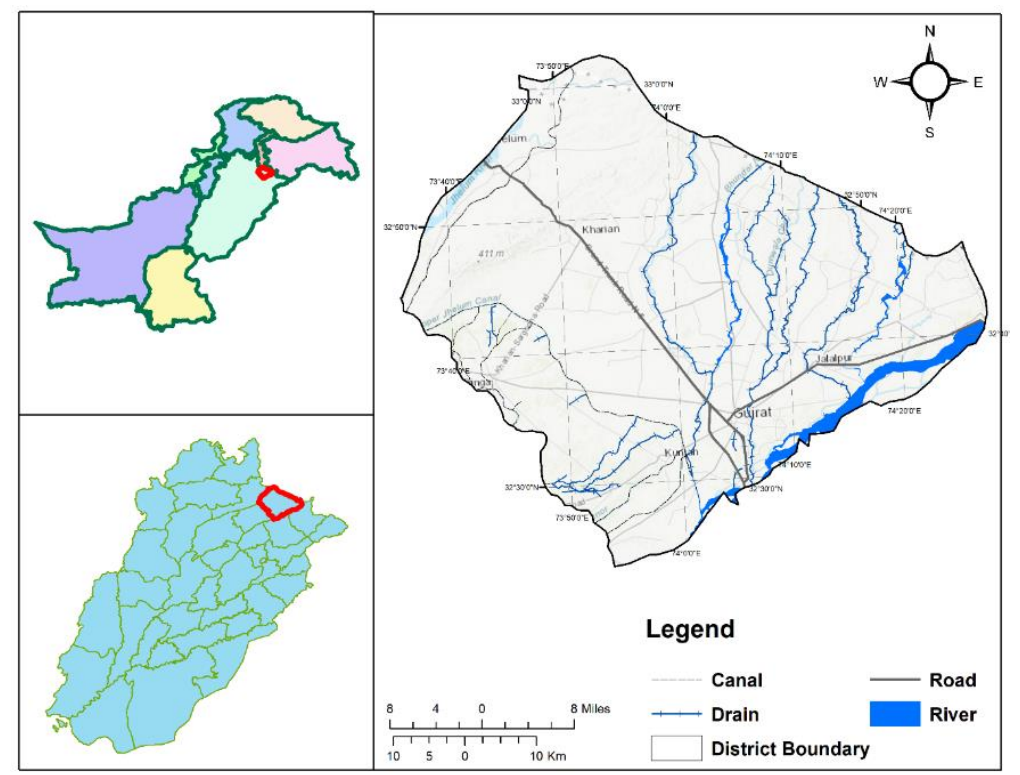

Figure 1. Map of Pakistan showing the study area

The district is divided into four tehsils of administrative hierarchy namely, Gujrat, Kharian, Sarai Alamgir, and Jalalpur Jattan (Plannning, 1999). The tehsil of Gujrat itself is divided into 65 smaller administrative units called Union Councils. The city is run by a bureaucratic setup which is a mixture of elected and appointed members.

Gujrat is among one of the oldest centers of civilization in the region. Imperial Gazetteer of India traces its history back to Mauryan conquest in 332 BC. By 8th century AD the city was 
existing as metropolis of considerable importance. The city was given the status of district by the Mughal Emperor Akbar, making it one of the oldest districts of Punjab. In the British era the city witnessed a lot of war and violence.(Hussain, Nisar, Majeed, Nawaz, \& Bhatti, 2010) City's growth spurt started after the birth of Pakistan.

Gujrat's waste is not getting deposited properly. The city due to its rapid industrialization produces 210.42 tons of solid waste daily. Per capita production stands at $0.5 \mathrm{~kg} / \mathrm{day}$ which is likely to rise. A whopping $10 \%$ of the solid waste produced in the district is non-degradable plastic, which requires highly developed disposing infrastructure. Unfortunately, the city lacks even a single solid waste treatment plant ("Muncipal Corporation Gujrat," 2019). The only way of waste disposal is landfill, such as Sheikh Sukha landfill site located $12 \mathrm{~km}$ away from Gujrat city. This method is highly questionable and clearly insufficient to cater the needs.

\section{Methodology}

Two types of data collection were used i.e. primary and secondary. Secondary data was collected from Tehsil Municipal Administration (TMA) office Gujrat, while the primary data was collected from general public in Gujrat city. The main source of urban flooding data is primary. The depth of stagnant flood water was measured with help of a 100 inches long scale during April, June, July, August and September 2018. This data was later integrated with ArcGIS and maps were generated to show the low lying and faulty areas. 10 spots were selected in Gujrat city, and the depth of water was being constantly measured for 10 heavy rainfalls. To ensure that all heavy rainfalls are measures, weather forecasting data was collected from metrology office located in University of Gujrat and Jehlum. Methodology framework of the study is also represented in Figure 2.

The data collection phase started after problem indication, which was further divided in two subcategories, primary and secondary. Primary data was collected by the researcher herself when she visited the city's waste collection and dumping sites. However, the secondary data was collected from TMA (Tehsil Municipal Authority, Gujrat) and urban planning unit. After the data completion phase, a detailed analysis was carried out through different software, i.e. ArcGIS, MS Excel, and SPSS. 


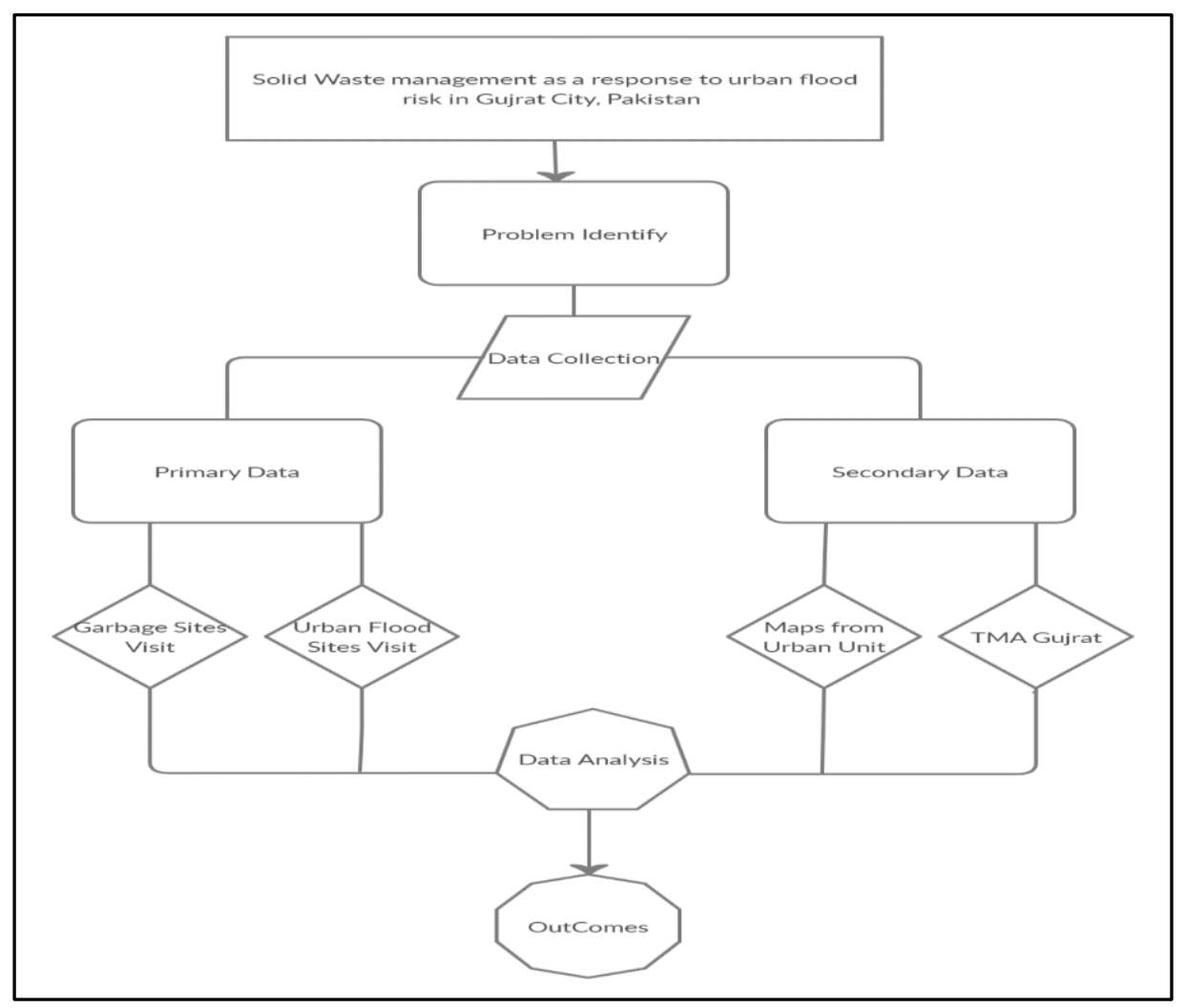

Figure 2. Methodology of the research work

\section{Data Processing}

All numeric data either processed in Ms word or GIS depend upon the requirements, like table and graphs created by Ms word while Interpolation processed in GIS, is a technique which develop surface data by processing point data. That point data has values of certain location from which unknown data set values identified (Zhao \& Zong, 2018). There are different types of interpolation functions applied to calculate unknown values; however Inverse Distance weightage (IDW) is one of the most common frequently applied techniques. IDW is comparatively fast, reliable, easy to calculate and straightforward to interpret. This technique generally follows the geography first law which says that everything is related to everything but nearer thing related more. Inverse Distance Weightage working based on the assumption that the attribute values of unknown point is actually the weighted average of known values within neighbourhood. And there weight is in inverse relationship between the distance of prediction location and the sampled locations (Lu \& Wong, 2008). IDW technique applied on known points values to locate other urban flood prone sites of the city. Ten different location of city identify which mainly faced urban flood in rainy season and that identity points were consecutively record on each rainy day. Captured data arranged and made it compatible with the software ArcGIS. As data entered was further processed through IDW, where urban flood on unknown points were also computed. 


\section{Results and discussion}

The rainfall measured in Gujrat city over a specific time period and shown in the Figure 3 . The depth of stagnant flood water was measured with the help of a 100 inches long scale. During the months of April, June, July, August and September, 2018. Gujrat city received almost 450mm rain. A few areas receive mild rainfalls ranging up to $6 \mathrm{~mm}$, while others were as heavy as $38 \mathrm{~mm}$. 10 consecutive heavy rainfalls were recorded and the magnitude of urban flooding in Gujrat was measured in the light of that record (Pakistan Meteorological Department, 2019).

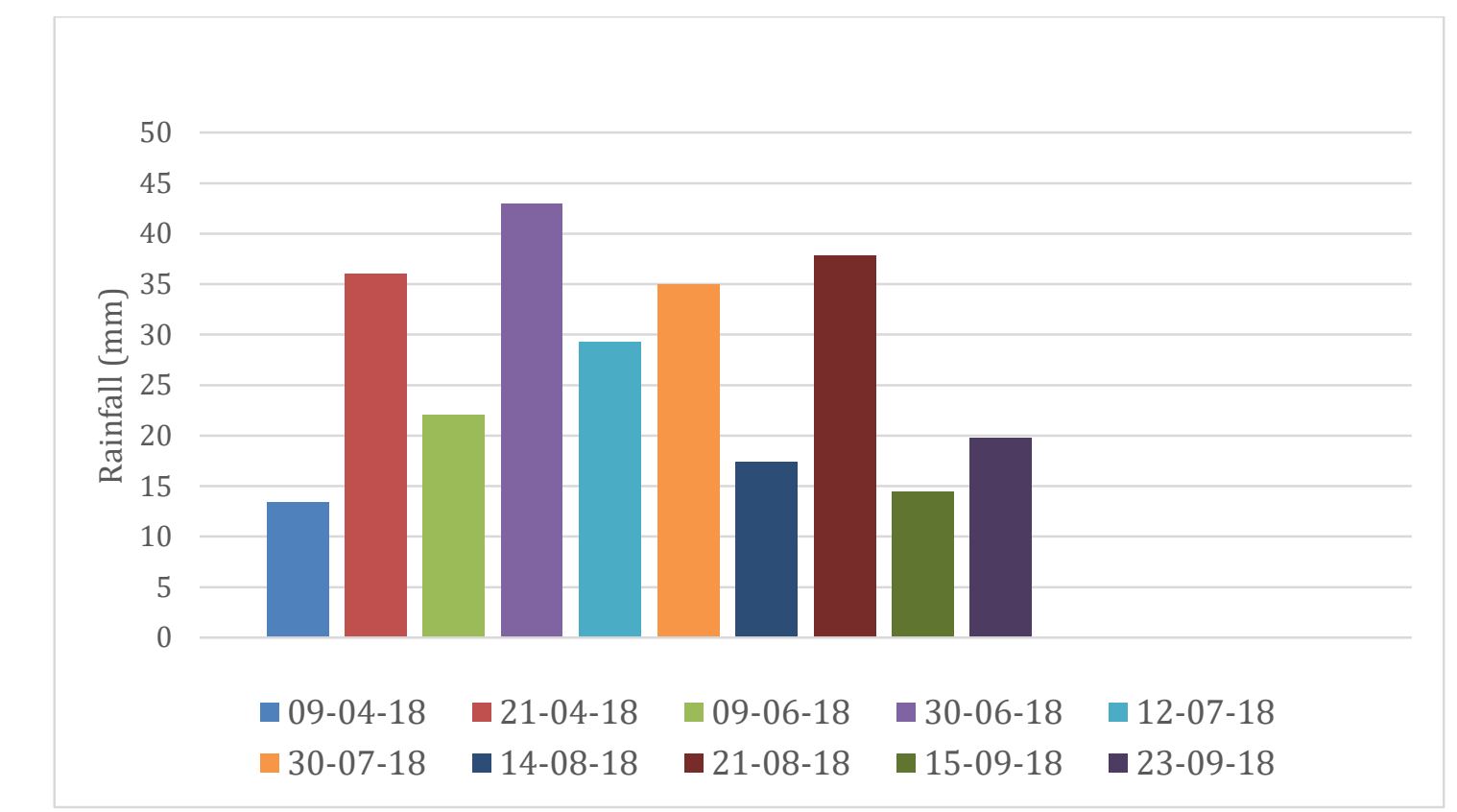

Source: Pakistan Meteorological Department

Figure 3. Rainfall in the city during study period

The TMA dustbin installed in Fawara chowk was filled with rain water; the waste was floating on the road and eventually started accumulating in the drainage pipe near girls hostel located in Fawara chowk. This routine is common in all parts of the city, as dustbins are open. People throw waste outside the bins and it reaches the already deficient drainage system and increase the magnitude of urban flooding. Gujrat received $36 \mathrm{~mm}$ rain of 21 April 2018. Similarly, on 30th June 2018, 43mm rainfall was recorded by the meteorological office, (Pakistan Meteorological Department, 2019) this figure is considered as heavy rainfall and the whole city sunk after it. Due to the continuous rainfall, there was no public transport available and many points could not be recorded.

However, after 43mm rainfall, 37 inches water was accumulated in Fawara chowk. Almost 3 feet of accumulated water had made public movement impossible. Various vehicles were stuck in the water and some accidents were also recorded. Luckily there was no life loss during the heavy rainfall and storm. Inverse distance weight based urban flood map has highlights the hotspot areas of the city facing major urban flood conditions. Here are detailed IDW maps (Figure 4, 5) in of low lying areas in Gujrat which always face urban flooding. 


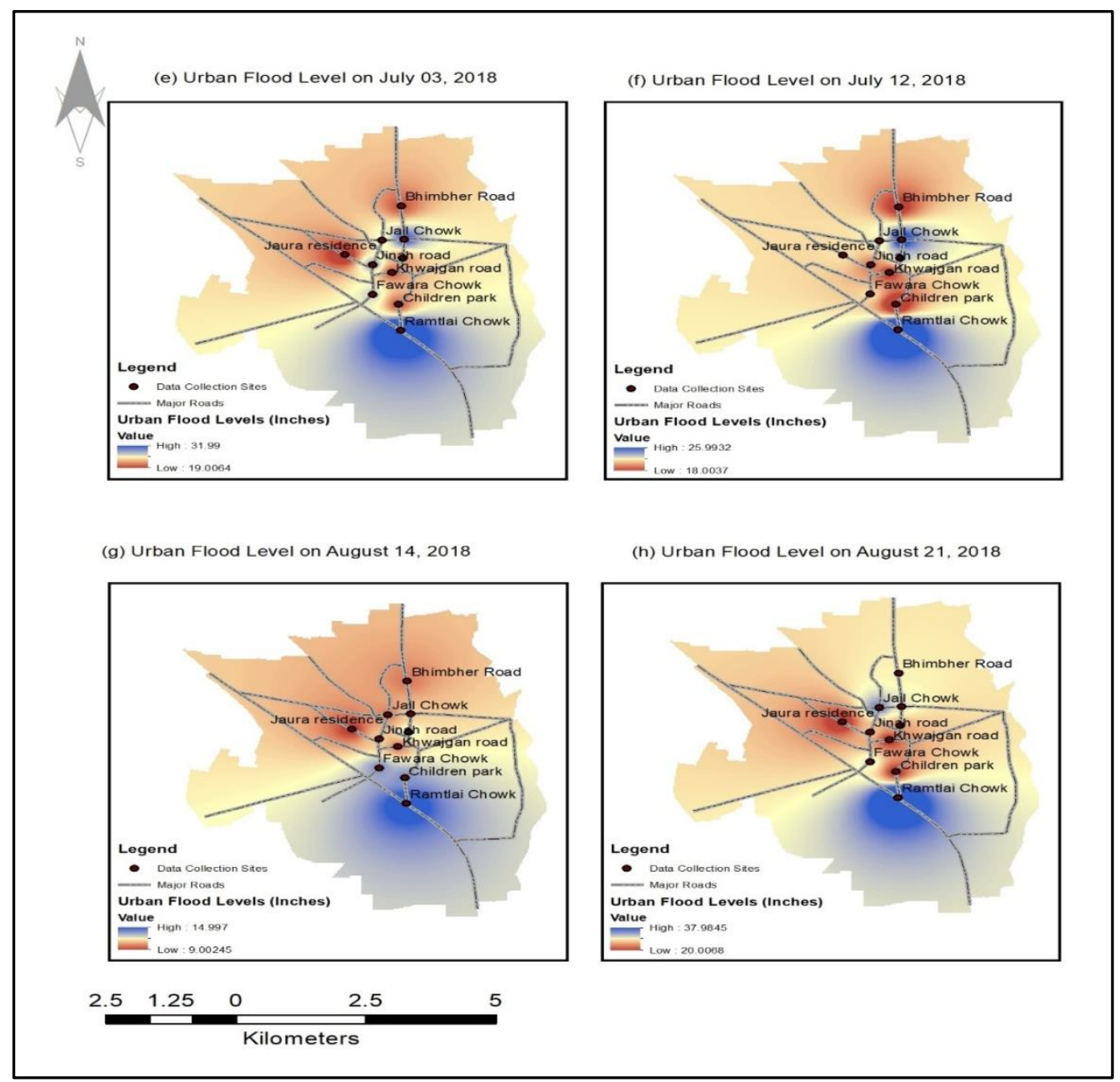

Figure 4. Urban flood level-using interpolation method (IDW)

On 3rd and 12th July, 2018 about 35 and $29.3 \mathrm{~mm}$ of rainfall recorded by operational meteorological office operated within the city, while highest flood level recorded is 32 and 26 inches on Ramtlai chowk. On the other hand minimum flood level observed on Bhimber road and Jaura house. As most residential colonies are on a higher level than roads, their water flow is also towards the roads. When sewerage systems starts overflowing, roads are sunk in with dirty sewerage and rain water. The road in front of Central Jail faces almost 2 feet of urban flooding in each rainy season. This not only makes vehicle movement difficult, but the threat of electricity failure also increases. While rainfall on 14th and 21st August, 2018 were ranging from 17.4 and $37.2 \mathrm{~mm}$. about 37 inches flood level acquired in case of rainfall held on 21st of August while 14 inches recorded on 14th August rainfall. 


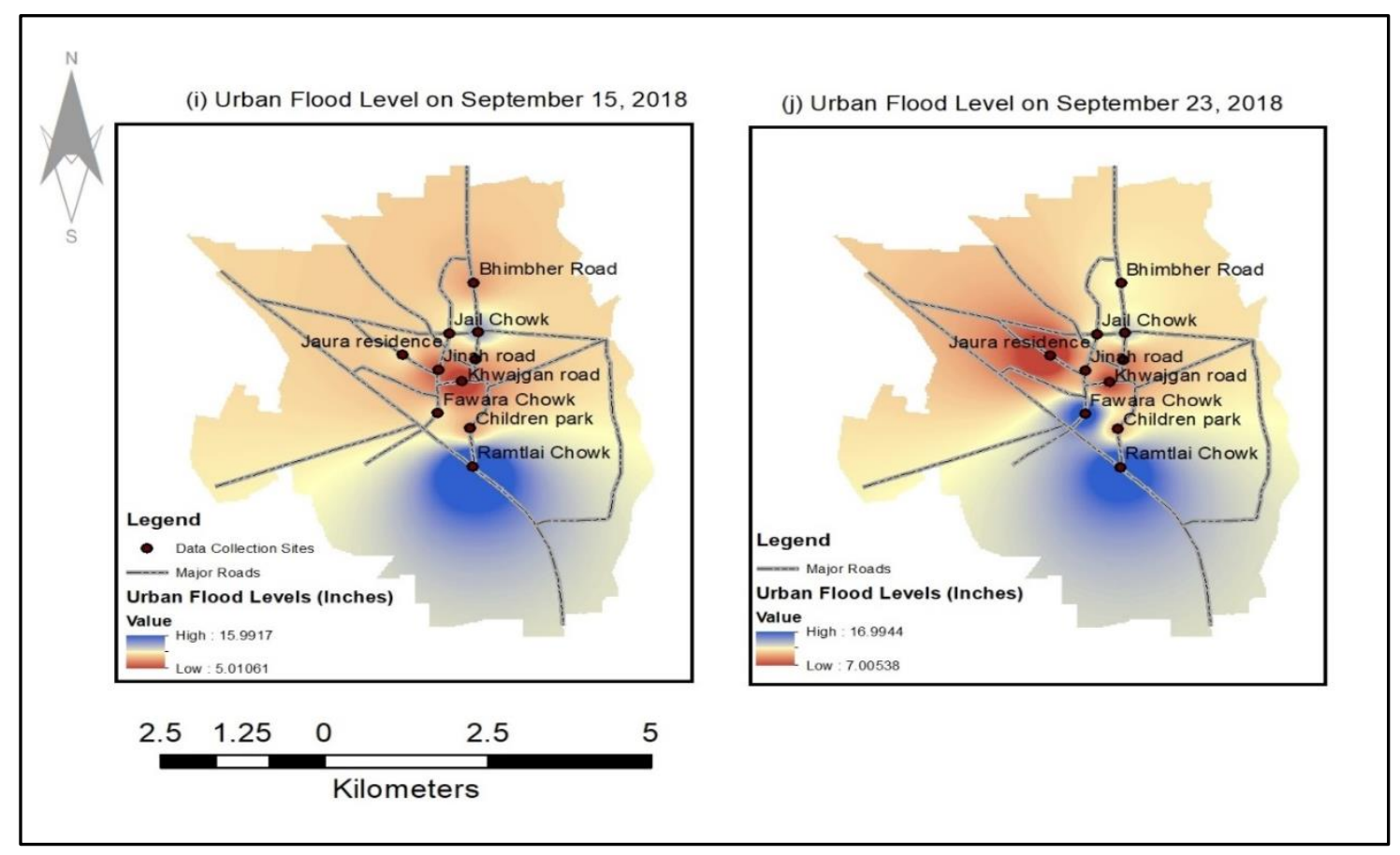

Figure 5. Urban flood level using interpolation (IDW)

On September 15 and 23 of 2018 rainfall recorded by the observatory was 14.5 and 19.8 mm respectively. Figures 4 and 5 were generated by applying IDW technique which reflects urban flood prone areas of the cities, it is clear from maps that hotspot areas were southern areas such as Ramtlai chowk where flood level measured was up to 15 inches while in the mid of the city flood level was raging between 5 to 10 inches.

According to the measurements, all major junctions in Gujrat city remain flooded for 5-7 hours after each rainfall. And sometimes this duration prolongs to 3-4 days. In Fawara chowk, the amount of rainfall is directly proportional to the depth of stagnant water because there is no passage for water once it starts raining. The existing drains remain fill with waste material and cannot support rainwater. Consequently, the area from Fawara chowk till Prince Chowk becomes the most problematic area. Once the rain stops, it takes 3 hours before water level starts decreasing. On 13th April 2018, 13.4mm rain was recorded in Gujrat. The scale of urban flooding was measured 1-2 hours after the rainfall in all marked location. There was no significant decrease in water level for 3 hours. After that, the water level slowly decreases and the roads return to their original state. Same results recorded for the rainfall on 21st April as shown on map.

During the Monsoon season, collection and disposal of solid waste is heavily affected as shown in Figure 6. Most discarded material becomes soaked in water because the collection points are open. When the collection vehicle transfers waste from these small points to larger containers, they have to put in double effort. Because water increases the weight of solid waste. People avoid going out to dump their household waste during wet season and the workload on TMA sanitary cleaners also increases. Saint Saver's church located on Bhimbher road Gujrat was worst hit by urban flood and sewerage water in 2016. The reason behind this mishap was reshaping of adjacent drainage system by TMA Gujrat because the reshaping was not properly planned. As a result, solid waste was largely accumulated in the drain near Saint Saver's church and during the monsoon season, dirty sewerage water started rushing in. As a consequence, church administration was 
unable to conduct weekly prayer service. The waste water swamped the flooring and carpets of the church which caused great nuisance to the church administration.

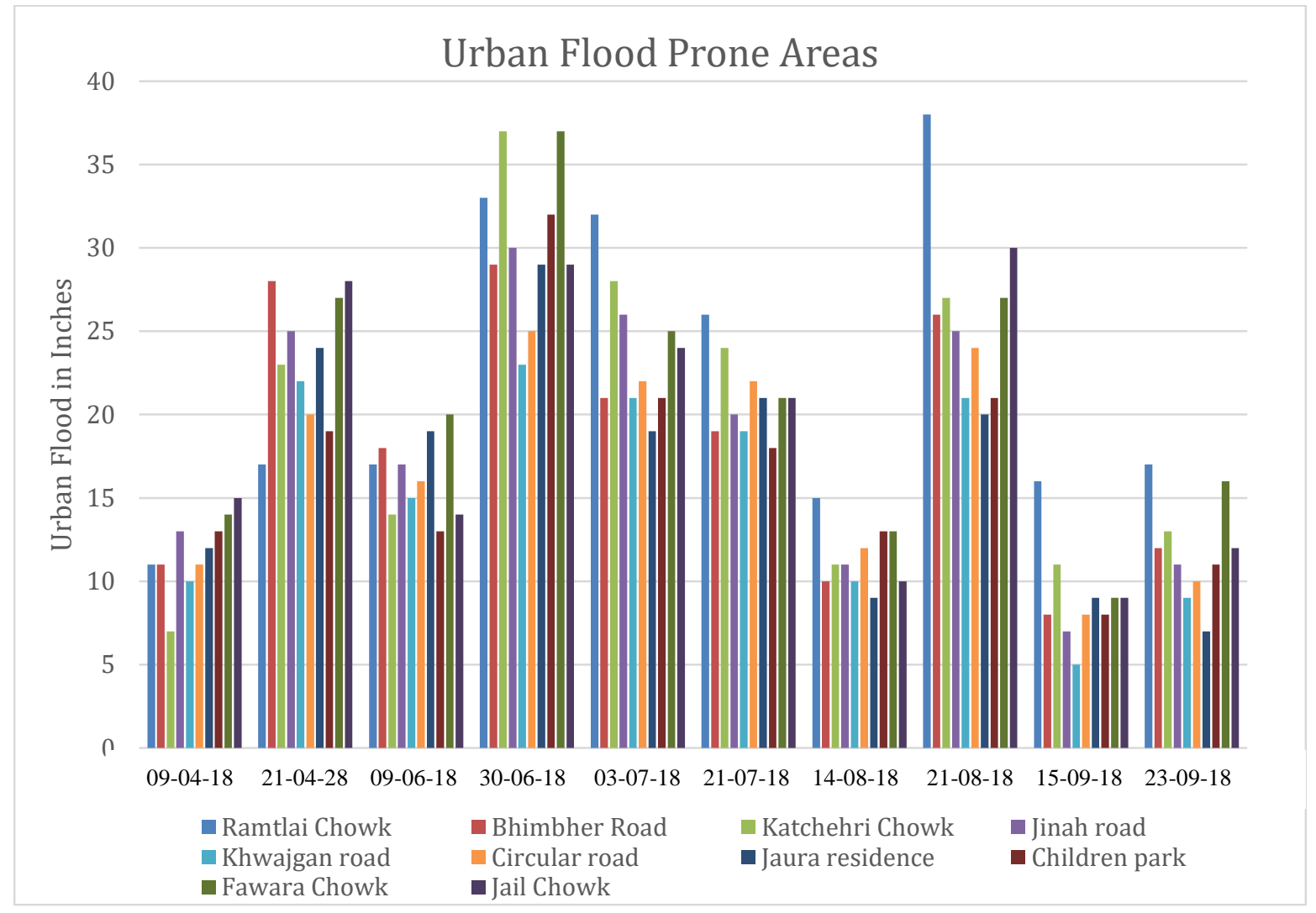

Figure 6. Urban flood areas- date-wise

City's drains and disposal sites are under the surveillance of Tehsil Municipal Authority (TMA) whose head office is on circular road near Fawara Chowk. From there, the waste collection vehicles drive off for the city, pick and dump the waste, and are parked back in the TMA building. However, the major flaw in this system is lack of planning and management. The sewerage lines are old and do not cater to the needs of the whole city. According to Urban Unit (n.d.), these lines only cover $60 \%$ area of Gujrat, and the remainder is left unchecked. The city lacks in many aspects:

Firstly, the drains are open and people throw waste in them which eventually leads to the blockage. Once there is a drainage blockage, the response of TMA is sluggish. On average, TMA takes 4-7 days to clear the drainage jams. Mostly, sanitary workers remove the waste stuck in drains, and leave it there un-picked. This lack of responsibility creates smell, germs, and toxic gases in the residential areas. Mosquitos and fleas start increasing because of that uncollected waste and become root cause of numerous viral infections. After every rainy season, gastric and skin diseases breakout in Gujrat.

Secondly, a large portion of Gujrat does not have drains; the area form Jaura residence to Sufi hotel does not have a constructed drainage line. People have installed temporary pipes and have constructed drains to give their waste water a passage till Bolay Pull which is the major disposal site of the city. Similarly Jail Chowk does not have a drainage line. Opposite side of 
Doctors hospital where DCO, DDO, and DPO houses are located, the rain water does not have a passage. Even after a mild rainfall, water accumulates there and stays for 2-3 days on generally.

Thirdly, as solid waste causes blockages, there are no restrictions on the installation of large dustbins near the major drainage lines. On Jinnah road, there is a junction of 3 drains i.e. from link Jinnah, Ghareeb Pura and Khwajgan road which causes a heavy urban flood in each season. The waste workers do not care if the drainage will get blocked, and dump the waste around dustbins. The residents of city are equally careless about the already lacking drainage system; they throw plastic and organic waste in drains which accumulates in the sewers. During Monsoon and other rainy seasons, these filled sewers do not let the water flow.

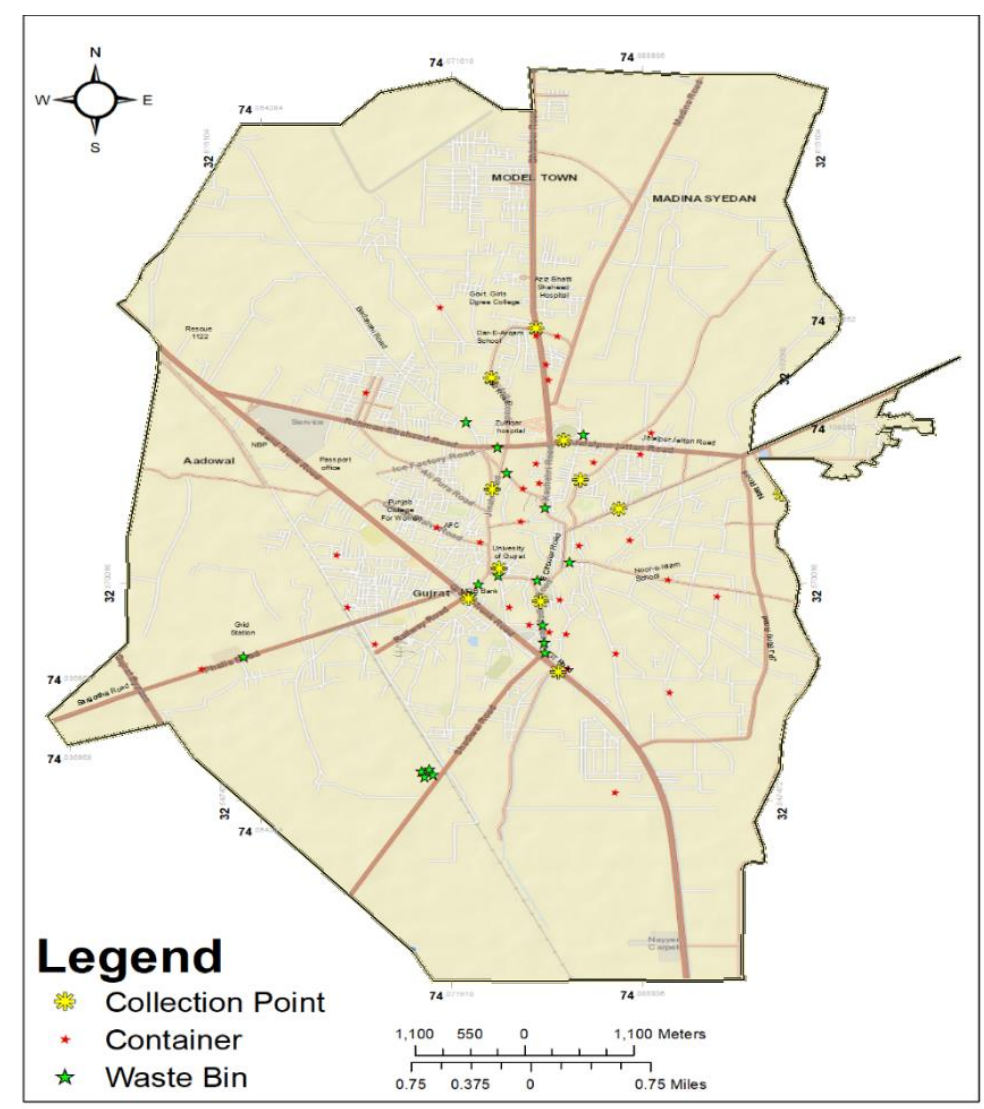

Figure 7. Map of the collection points, containers and waste bin

Rapid growth in Gujrat's built-up area and unplanned construction has made the vehicles' movement difficult. The streets which were wide enough to let the big vehicles pass have narrowed down and management authorities face trouble during their duties. When vehicles cannot access waste bins, sanitary cleaners pick them up and throw the waste in the TMA vehicle. This process takes additional time, manpower and the environment also becomes polluted through this careless practise.

When the TMA vehicles cannot access a dumping site, the sanitary workers do not collect waste from there and the problem of drainage blockage starts rising there. In the residential colonies near Children Park, TMA workers come to collect waste after 3-7 days because the streets there are very narrow and vehicles cannot reach the dustbins. Picking and moving large dustbins without the availability of automobiles is time-consuming, hectic and disorganized. 
If a rain sewer is clean, it lets the rain water flow easily and does not overflow very often. Similarly, if the way of water is blocked with plastic bags, water bottles, fruit peeling and cardboards, the water overflows from the sewers and urban flooding occurs.

Figure 8 representing the urban flood due to blockage of drains in the study area. According to $66 \%$ sanitary workers, solid waste gets accumulated in the drains and they start overflowing. Further shedding some light on this issue, one of the sanitary workers said that people do this willingly. According to him, a portion of public finds it derogatory to pick throw their household waste in the dustbins. They wash all waste out in the drains, and it becomes a blazing problem. Throwing solid waste in the drains is most common in Islam Nagar, Fattuh pura, Muslim bazar, and Qamar Sialvi road. Apart from this one sanitary worker, others stated that people do not do it intentionally. Instead, the lack of dumping facilities leads them to throw waste in open plots. And with time, wind moves this waste to drains.

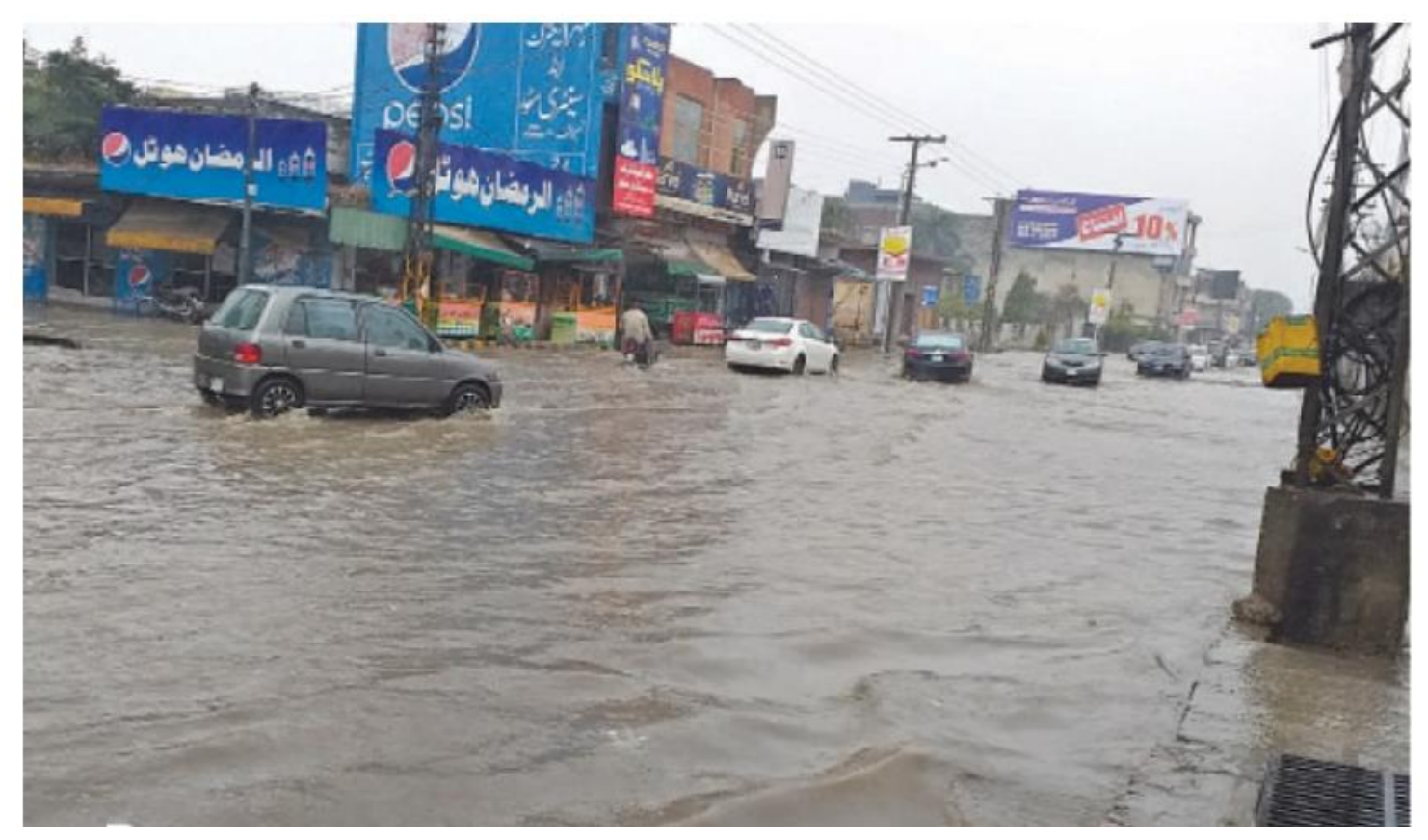

Figure 8. Snapshot of the road after one day of raining in Gujrat city

\section{Conclusion}

General public's buying capacity increases the problems for city's sanitary staff, evidenced by the poor waste collection facilities. There is one sanitary cleaner for 900 people, and as the drainage network of Gujrat is poorly constructed, this number in not justifiable. The vehicles which government has provided for solid waste management and drains cleaning are not efficient. Lack of social acceptability of sanitary workers discourages them and they do not perform their duty efficiently. People do not want to be recruited in TMA department because of the low wages and overburdening of work. This research has proved the inability of TMA Gujrat in the department of SWM. Despite being the only responsible authority for SWM, it does not have a strategy to properly dispose the city's waste and keep the drains free from waste accumulation. The drainage system is not covering $40 \%$ residential area which makes the whole system more problematic. This study concludes that installation of new waste dumping sites and sewerage facilities is unavoidable 
for Gujrat City. We observed that areas with well-planned and sufficient waste facilities are less prone to urban flooding. On the contrary, localities with insufficient and unplanned dumping sites were the most affected by urban flooding.

\section{References}

Batool, S. A., \& Ch, M. N. (2009). Municipal solid waste management in Lahore city district, Pakistan. Waste management, 29(6), 1971-1981.

Bhada, P. (2007). Feasibility analysis of waste-to-energy as a key component of integrated solid waste management in Mumbai, India (Master thesis). Retrieved from Department of Earth and Environmental Engineering, Columbia University.

Bolund, P., \& Hunhammar, S. (1999). Ecosystem services in urban areas. Ecological economics, 29(2), 293-301.

Estoque, R. C., \& Murayama, Y. (2013). City profile: Baguio. Cities, 30, 240-251.

Guerrero, L. A., Maas, G., \& Hogland, W. (2013). Solid waste management challenges for cities in developing countries. Waste management, 33(1), 220-232.

Gupta, A. K., \& Nair, S. S. (2011). Urban floods in Bangalore and Chennai: risk management challenges and lessons for sustainable urban ecology. Current Science, 1638-1645.

Hoornweg, D., \& Bhada-Tata, P. (2012). What a waste: a global review of solid waste management. Urban development series; knowledge papers no. 15. World Bank, Washington, DC. Retrieved from https://openknowledge.worldbank.org/handle/ 10986/17388

Hussain, K., Nisar, M. F., Majeed, A., Nawaz, K., \& Bhatti, K. H. (2010). Ethnomedicinal survey for important plants of Jalalpur Jattan, district Gujrat, Punjab, Pakistan. Ethnobotanical Leaflets, 2010(7), 11.

Khan, B., Iqbal, M. J., \& Yosufzai, M. A. K. (2011). Flood risk assessment of river Indus of Pakistan. Arabian Journal of Geosciences, 4(1-2), 115-122.

Lamond, J., Bhattacharya, N., \& Bloch, R. (2012). The role of solid waste management as a response to urban flood risk in developing countries, a case study analysis. WIT Transactions on Ecology and the Environment, 159, 193-204.

Lu, G. Y., \& Wong, D. W. (2008). An adaptive inverse-distance weighting spatial interpolation technique. Computers \& Geosciences, 34(9), 1044-1055.

Mukwana, K. C., Samo, S. R., Tunio, M. M., Jakhrani, A. Q., \& Luhur, M. R. (2014). Study of Energy potential from municipal solid waste of Mirpurkhas City. Quaid-e-Awam University Research Journal of Engineering, Science \& Technology, 13(2), 26-28.

Muncipal Corporation Gujrat. (2019). Retrieved from https://www.mcgujrat.lgpunjab. org.pk/

Muthuraman, L., \& Ramaswamy, S. (2019). Solid Waste Management: MJP Publisher.

Pakistan Meteorological Department. (2019). Retrieved from https://www.pmd.gov.pk/en/

Plannning, H. a. P. (1999). Gujrat Revision / Updation of outline Development Plan 1999-2024: Office of the Deputy Director Regional Physical Planning Rawalpindi.

Radha, K., Kalaivani, K., \& Lavanya, R. (2009). A case study of biomedical waste management in hospitals. Global Journal of Health Science, 1(1), 82-88.

Rajor, A., Xaxa, M., \& Mehta, R. (2012). An overview on characterization, utilization and leachate analysis of biomedical waste incinerator ash. Journal of Environmental Management, 108, $36-41$. 
Raju, K., Ravindra, A., Manasi, S., Smitha, K., \& Srinivas, R. (2018). Trends and status of environmental resource use in Bengaluru Metropolitan Area (BMA) Urban Environmental Governance in India (pp. 109-247): Springer.

Rehman, H., Chaudhry, A. G., \& Nasir, A. (2015). Nala Lai and urban ecology: A study of dwellers and disaster management. Pak. Assoc. Anthropol, 27, 617-619.

Shekdar, A. V. (2009). Sustainable solid waste management: an integrated approach for Asian countries. Waste management, 29(4), 1438-1448.

SPOANN, V. (2019). Assessment of municipal solid waste management capacity of local government authorities and contracted waste collection service: A case study of Phnom Penh Capital, Cambodia.

Tukahirwa, J. T., Mol, A. P., \& Oosterveer, P. (2010). Civil society participation in urban sanitation and solid waste management in Uganda. Local Environment, 15(1), 1-14.

Urban Unit. (n.d.). Gujrat City Profile. Punjab cities improvement investment program. Retrieved from https://urbanunit.gov.pk/Upload/Photos/107.pdf.

Zhao, J., \& Zong, H. (2018). Solving the multiple-set split equality common fixed-point problem of firmly quasi-nonexpansive operators. Journal of Inequalities and Applications, 2018(1), 83. 